\title{
Drivers for the use of materials across countries
}

Originally published as:

Sören Steger, Raimund Bleischwitz (2011):

Drivers for the use of materials across countries In: Journal of Cleaner Production, 19, 816-826 
Sören Steger ${ }^{\mathrm{a}^{*}}$, Raimund Bleischwitz ${ }^{\mathrm{a}}$

\section{Drivers for the use of materials across countries}

a Wuppertal Institute for Climate, Environment, Energy, Wuppertal, Germany

* Corresponding author: Sören Steger, Wuppertal Institute for Climate, Environment, Energy, Doppersberg 19, Wuppertal 42103, Germany

E-mail: soeren.steger@wupperinst.org

Phone: +49-202-2492-162

Fax: $+49-202-2492-138$ 


\title{
Drivers for the use of materials across countries
}

\author{
Sören Steger* / Raimund Bleischwitz
}

Final draft, as of June 8, 2010

Submitted to Journal for Cleaner Production, Special Issue Utrecht 2009

Wordcount: 7665

\section{Abstract}

This paper analyses drivers for resource use and material productivity across countries. This is not only relevant in light of soaring raw material prices but also because EU policies, such as the 'Thematic Strategy on the Sustainable Use of Natural Resources' (COM[2005]670), the EU Raw Materials Initiative (COM[2008]699) and various similar policies internationally, seek to better manage materials along their life-cycle and across economies. In order to better understand the system dynamics of material use, our paper applies methodologies of material flow analysis and regression analysis to identify the major drivers for resource use and decoupling from GDP. Drivers are understood as those factors that exert influence on human activities to use resources. A panel data set is taken for the European Union for the years 1980 - 2000 (EU-15) and 1992 - 2000 (EU-25). The main drivers of resource use were found to be energy efficiency, new dwellings and roads construction activities. Shortcomings of the methodology are also discussed.

JEL-Code: C30, F 43, O13, O57, Q31

Keywords: Drivers, Decoupling, MFA, Regression Analysis 


\section{Introduction}

After the bailout of the financial crisis, forecasts over future raw material demand have become quite uncertain. Many observers believe that sooner or later markets will reassemble and demand will continue to increase, especially considering growth patterns in emerging economies such as China. Variations however are enormous. Most economies will manage a relative 'decoupling' between GDP on the one hand and the use of natural resources and energy carriers on the other. Still others predict that policies on climate and energy will have an impact on demand patterns. If such policies succeed to reduce the emissions of $\mathrm{CO}_{2}$ by some $80-95 \%$ by the year 2050 , as e.g. the Intergovernmental Panel on Climate Change (IPCC) has suggested and the EU has adopted prior to the Copenhagen Conference in late 2009, the ensuing development patterns towards a low carbon economy and the demand for clean technologies will definitely affect the use of resources and probably strengthen attempts to increase the resource productivity and dematerialisation of economies worldwide.

Any such development however needs a thorough understanding of system dynamics to assess changing resource-intensive production and consumption patterns of economies. One method is to analyses drivers. Drivers are understood as those factors that exert influence on human activities to use resources. The aim of our paper is to analyse the interaction between such variables over time across a number of countries. Although the identification of structural or causal relationships is a difficult task, our attempt is to derive empirical evidence on a limited set of drivers that account for a relevant share of decisions on resource use across all major economies. 
This approach is expected to shed light on why some countries at a comparable stage of development use more and others less of resources over time and what common factors can be identified across countries. This is important because up until now just a few countries have been able to reduce the use of materials in absolute terms (Krausmann et al. [36]; Steger \& Bleischwitz [51]; Weisz et al. [61], Bringezu [16]) and understanding drivers is a necessary precondition towards sustainable resource management (Bringe$\mathrm{zu} /$ Bleischwitz [18]). Our approach is new because prevailing research has focussed on long-term trends (Krausmann et al. [36]), on global extraction patterns and trends (Giljum et al. [25]), on different patterns of material use across countries (Weisz et al. [58], [59]), and on decoupling pathways (Bringezu et al. [17]). The only study known to us, which selects a similar approach, is van der Voet et al. [54]. The measurement methodology of Material Flows Analysis (MFA) is taken from the OECD [44] as well as from Bringezu/Bleischwitz [18].

Following an interaction between recent theory and data, our paper has chosen the methodology of regression analysis to discuss statistically significant findings and to arrive at conclusions. Data set is taken for the European Union for the years 1980 2000 (EU-15) and $1992-2000$ (EU-27). Analysis of features specific to countries can be undertaken with a similar methodology, but this was beyond the scope of this paper. The paper is structured as follows: Chapter (2) introduces the methodology; it gives an overview of the theoretical approach and a definition of drivers, discusses the validity of regression analyses and concludes on the variables derived for the purpose of this paper. Chapter (3) reveals the results of our analysis. Chapter (4) discusses the findings and arrives at tentative conclusions on lessons learned for the international political economy. 


\section{Methodology: analysing drivers}

\subsection{The interaction between theories and empirical analysis}

Establishing structural or causal relationships is a difficult task. Until now, the quest for a mechanical algorithm for determining causality from data has not yet led to a successful discovery. On the other hand, the Haavelmo ideal of introducing causal parameters produced from well-defined structural economic models derived from explicitly articulated axioms seems rather rigid for empirical analysis. As a way out of this dilemma situation, our paper starts from the insight that an interaction between theory and data is likely to create robust empirical knowledge (Heckman [30]).

As a general background, theories of socio-economic change such as Nelson/Winter [40], [41], North [43], the new growth theory (Bretschger [14], [15]) and the findings of Elinor Ostrom (e.g. [46]) on collective action provide a good understanding on why economies and social groups have been following quite different pathways and dynamics over time. Bleischwitz [7] and Bleischwitz/Welfens/Zhang [12] had pointed out the relevance of labour productivity for prevailing trajectories of innovation and growth. With regard to decoupling, in particular the intensity of use-hypothesis developed by Malenbaum [39] and the derived discussion about an Environmental Kuznets Curve $(\mathrm{EKC})^{1}$ can be seen as relevant approaches. Both approaches state that countries follow a pathway of industrialisation according to which they specialize first in heavy industry to meet the demand for houses and infrastructure and gradually shift to lighter industries and services. Malenbaum expected that at a certain point in time the consumption of

1 There is a wide literature about EKC and although the empirical results are often weak, the concept of the EKC offers a suitable approach for a first choice of variables. 
different materials would even fall in absolute terms - a quasi determinism that hasn't occurred yet as a general trend. Keeping these theories and empirical evidence in mind, it seems useful to distinguish four general pillars for the identification of drivers (see also Cleveland and Ruth [22]):

1) Technological progress: The development of new products, services and materials allows the same volume of goods and services to be produced with fewer raw materials. Economies may gain competitive advantages from saving material purchasing costs and innovating in that direction. Substitution of scarce and/or environmentally harmful materials by new materials may also offer new ways of satisfying demand. However technological progress is open and has hardly a clear direction.

2) Structural change: A change in the structure of demand towards service sectors and new goods, e.g. Information and Communication Technology (ICT) products $^{2}$, which in turn may lead to either a decline of material-intensive industries or give incentives for sectoral innovation (Malerba 2007 [38]). Also, a change in consumer preferences towards less material needs (e.g. social well-being rather than purchasing products) can also result in a change of the structure of final demand. Both trends however can also lead to additional demand for resources (Jackson [34]; Scott [49]).

3) Saturation in infrastructure investments: Along with a higher level of development, the need for infrastructure investment declines and the building stock is nearing completion. As a result of such saturation effect, demand for mass commodities such as construction materials, iron and steel may begin to de-

2 ICT effects certainly are ambiguous; on the one hand ICT may save energy and materials, on the other hand critical materials are required and new demand is created. 
crease. On the other hand, there might be additional demand for more and/or larger dwellings resulting from higher incomes and changing social structures as well as material requirements for maintenance efforts.

4) New lifestyles for green markets: With rising per capita income, the demand for better environmental conditions usually increases. This leads to new "green" markets for environmental goods and services nationally and internationally, and - according to the Porter Hypothesis (see Porter et al [48], Ambec et al. [2], Wagner [56]) - to first mover or second mover advantages for those industries. Conversely however, a stringent national environmental policy may also force pollution intensive sectors to move to regions with more favorable policies. This is especially the case when abatement costs become too high (pollution havenhypothesis, see for example Brunnermeier \& Levinson [19] or Xing \& Kolstad [62]). Moreover, new lifestyles may not be environmentally sound or resourcesaving, but instead lead to an accelerated use of resources (see e.g. air travel patterns).

These four pillars of change thus have no direction towards resource savings per se they frame the debate but need to be supplemented by more specific drivers with a clearer indication of whether they lead to more or less resource use. To this end, recent debate has revealed findings on barriers and contradicting factors to any decoupling (Jackson [34]), which is in line with our concept of drivers (causal networks, multidirectional processes, see below). In a broader context, institutional factors like the trade policies of key countries, the scope of relevant legislation, e.g. on mining, recycling, waste, and macro-economic conditions will probably shape the amount of materials used across economies. To stress these points, this paper concludes from recent theories 
that the final resource use is not determined by simple factors such as raw material commodity prices or levels of income as Malenbaum [39] and a recent study by CE Delft suggest (de Bruyn et al. [23]), but can be tracked by means of material flow analysis enriched by socio-economic research.

In addition, factors that have an influence on the consumption patterns of economies, but cannot - or only marginally - be influenced politically play a role, e.g. climatic and topographic conditions, demographic development and population density as shaped by geographic conditions ${ }^{3}$.

\subsection{Conceptualizing "Drivers"}

The term "drivers" may sound as if actors deliberately chose to drive along a certain trajectory in a certain manner. Such connotation is misleading. The term stems from concepts developed by the UN Commission for Sustainable Development (CSD) and the OECD, which define drivers in its Driving Force-State-Response Model (DSR) as "human activities, processes, and patterns that impact on sustainable development" (OECD [45].) The subsequent European Environment Agency (EEA) DPSIR model (Driving Forces - Pressure - State - Impact - Response) (EEA [24]) advances the DSR model but introduces a more sectoral understanding of the term driving force to include aspects such as industries and transport.

These concepts have been thus developed in the context of policies and seem to suggest a clear-cut causality between human activities, processes and patterns that have an impact on the environment. Ideally, this causality could be expressed as a monocausal

3 See e.g. Japan and Australia as countries with unfavourable conditions in large parts. Japan's topography is made of mountains and has favoured big cities along the coastline; large parts of Australia are covered by desert. 
chain, with one specific driver causing certain impacts. In reality however, activities are influenced by a number of inconsistent forces and people respond to a variety of incentives. Our attempt, therefore, conceptualizes drivers as elements of causal networks rather than causal chains, taking into account recent findings on rationality and dynamic production and consumption patterns of modern societies (Bleischwitz [8], [9], [10]; Niemeijer / de Groot [42]; Scott [51]). Drivers are related to many other aspects, which have an impact on them. Typically, this is a multi-directional process with dynamic interactions on markets as well as a variety of more indirect interactions in many directions.

In this context, a heuristic definition of drivers can be formulated as follows: Drivers shall be understood as specific and evident factors leading to increased or reduced resource consumption in an economy. Their character might be direct or indirect, external to actors (such as policies) or internal (such as behavioural factors).

\subsection{Data and variable selection}

Our paper basically uses two different datasets: for the EU-15 countries, the data set ranges from 1980 to 2000 and for the new member states, data is available from 1992 to $2000{ }^{4}$ Since we are interested in both the development of material consumption over time as well as the differences in the level of per capita consumption between countries,

4 Direct Material Input (DMI) measures those materials that have been extracted or harvested from the environment and are used for further processing and consumption within the economy. It is composed of the domestic extraction of minerals, metals, fossil fuels, harvested biomass and imports of raw materials as well as semi-finished and finished products. The Domestic Material Consumption (DMC) is calculated by subtracting exports from DMI. Therefore DMC measures those materials that are used within the economy for consumption purposes. As an update of Direct Material Input (DMI)/Direct Material Consumption (DMC)-data until 2007 will be published by EUROSTAT in the next weeks, it would be coherent to update the database of the independent variables as well to 2007. However, the methodology for the calculation of DMI / DMC was revised. It is therefore uncertain whether the data series for the DMC and DMI will be consistent for the period 1980 to 2007. 
we used data as a pooled time-series (or time-series cross-sectional data). ${ }^{5}$ For this reason, variables were selected for which time series with yearly data were available. Potentially important drivers for which data were available for only a few years (e.g. innovation indicators, or data on the length of the road) should be tested with a panel analysis. Besides With the exception of data collected by Eurostat in recent years, there are large data gaps (e.g. percentage of university degrees in natural science and engineering per 1000 inhabitants), significant breaks in the existing time series for certain countries (e.g. road data in Italy), or completely missing values for individual countries (e.g. passenger-km in Belgium or Greece).

Moreover, the theoretical basis for explaining the material use of economies is in its infancy. This means that the potential number of independent variables is very large. Thus, the variables were chosen in a two-step procedure. Firstly, based on the few existing theoretical foundations, those variables most likely to influence material consumption were selected. In a further step, the availability of longer time series for the used data format of pooled time series was considered. As a result, we derived a first list of 68 variables (see Table A1), which was reduced to 33 potential drivers (Fig A1 and A2) after adjusting for multicollinearity between independent variables.

To improve the comparability of data, this paper used the data provided by international sources and only to the extent necessary from national statistical offices. The main data sources were Eurostat, KLEMS database, AMECO database as well as data from the IEA, OECD and the WRI.

5 For the pros and cons of pooled time series against pure panel studies see Beck/Katz [6] or Plümper et al. [47]. 
We ran our regression analyses from various datasets from different countries and periods of time for both the DMC per capita and material intensity measured as DMC in kilograms per 1,000 US\$ in purchasing power parity (PPP). All time-variant variables were used as logarithmic variables and show the direct impact of drivers on material consumption and material intensity. Definitions of DMC and material intensity follow the OECD [44] handbook. ${ }^{6}$ Stata version 11 was used to run the calculations.

\subsection{Quantitative Analysis}

Given the data availability, the time series are rather short and the panel of countries is not particularly extensive. To improve the sample, augment the number of degrees of freedom and enhance the quality of estimators, time-series cross-sectional (TSCS) data (another common name is "pooled time series") was used. Such data is composed of both a time-series and a cross section. Some methodological problems arise when one multiplies cross-sectional data with time-series data: Unlike large panels (such as household surveys), the individual data points in TSCS data are not independent from each other. The time series structure of individual countries has to be included in the overall panel and must be considered in the analysis and the selection of the estimator. As Baltagi [3] notes, it is also very likely that - due to the TSCS data designs - assumptions of the ordinary least squares (OLS) regression are violated.

First, we fitted our models with the standard fixed effects model and an AR(1)-process because of the autocorrelation in our data (see the wide range on OLS-regressions in

6 One should note the different scope of direct material productivity and total material productivity (excluding or including hidden flows and ecological rucksacks); see OECD [44] and WI's research on indicators e.g. Bringezu/Bleischwitz [18]. 
econometric textbooks for details e.g. Greene [27], Wooldridge [61], Hsiao [32]). ${ }^{7}$ For complying with the heteroscedastic residuals as well as the autocorrelation we then fitted our models with the PCSE method ${ }^{8}$ and included the disturbance term in a firstorder autoregressive form. In addition, we used country-dummies in the PCSE regression for dealing with the regular specification as a fixed-effects model.

A crucial question concerns the assumption of a linear relationship between independent and dependent variables. Little can be found in the literature so far with the exception of some studies on the relationship between GDP per capita and the consumption of resources (Canas et al. [20], Bringezu et al. [17], Weisz et al. [60], Weisz et al. [61]). If an EKC existed for resource use and per capita income, this would implicate a square function. However, Bringezu et al. [17] show that the statistical differences between a linear, a logarithmic and a quadratic function are extremely low when testing the EKC hypothesis between GDP per capita and DMI. On the one hand, all data points still stand on the left side of a possible peak point and, on the other hand, the slope of the coefficient is very flat, so there are almost no differences between a linear and logarithmic function. It is not very likely that the new results will differ when DMC instead of DMI is being used.

The most critical point of our regression estimates relates to the time series properties of our data. In general, the time series must be stationary in order to avoid spurious regressions (Granger/Newbold [26]). As known from the literature (i.e. Stock/Watson [52]),

\footnotetext{
7 If autocorrelation exists, one can either try to integrate the previous period as an explanatory variable in the model or transform the data in a way that allows to cope at least with first-order autocorrelation. To integrate the previous period as an explanatory variable in the investigation sounds initially plausible, but it has the great disadvantage that all other variables lose most of their explanatory power or even become insignificant, because the model is almost entirely explained from the data of the previous year (see Plümper et al. [47]).

8 In 1995, Beck and Katz (Beck\&Katz [5], Beck [4]]) published an influential paper which then became the standard for comparative studies pooling time series during the following years, especially in the field of political science. For critical review of the panel corrected standard error (PSCE) method see Kittel [35] and Wilson/Butler [60].
} 
many macroeconomic time series tend to be non-stationary. Only in recent years various tests have been developed which can test stationarity in pooled time series (Breitung\&Das [13], Choi [21], Hadri [28], Harris\&Tzavalis [29], Im et al. [33], Levin et al. [37]). In the newest Stata version (Stata 11), these tests are now included and available for research. We have started to conduct such tests. Tentative results, however, are mixed or ambiguous. If our data are non-stationary, we can either take the first difference to analyse the short-term relation between the variables or test whether our variables are co-integrated with the dependent variable. But the issue of the co-integration test for pooled time series data are just now being worked out (Westerlund [57] Becks/Katz [6]) and suffers in general from our small time series. 


\section{Discussion of Results}

Table 1 shows the test statistic for the panel of the EU-15 countries for the period from 1980 to 2000 . The very high $\mathrm{R}^{2}$ is explained by the estimate of the model with countrydummies $^{9}$. All explanatory variables lie within the $5 \%$ significance level. Since all the variables were used as log-variables, the coefficients directly reflect the importance of each variable.

Table 1: Drivers for Domestic Material Consumption per capita Test statistic for EU-15, 1980-2000

\begin{tabular}{lc} 
DMC per cap for EU15 1980-200 \\
\hline fec_cap & $0,178^{* *}$ \\
& $(0,075)$ \\
mw_cap & $0,078^{* * *}$ \\
& $(0,015)$ \\
dw_com & $0,076^{* * *}$ \\
& $(0,023)$ \\
heat & $0,005^{* * *}$ \\
& $(0,001)$ \\
imsha & $0,225^{* * *}$ \\
& $(0,085)$ \\
year & $-0,013^{* * *}$ \\
& $(0,004)$ \\
& \\
\hline \multirow{2}{*}{$\mathrm{N}$} & 191 \\
Groups & 14 \\
rho & 0,52 \\
\hline
\end{tabular}

Notes: Best-fit model with panel corerected standard errors (PCSE), country dummies and common AR(1)-process. Standard errors in brackets. ${ }^{* * *}$ significant at the $1 \%$-level; ${ }^{* *}$ significant at the $5 \%$-level; ${ }^{*}$ significant at the $10 \%-l e v e l$.

In the best-fit model for the panel EU-15 and the period from 1980 to 2000 the important variables related to the DMC per capita are as follows: energy consumption per capita (fec_cap), the length of motorways per capita (mw_cap), the number of completed dwelling units (dw_com) and the share of import of GDP (imsha). Climate conditions such as heating days (heat) also influence the DMC per capita. The

9 All regressions are calculated with country-dummies, but we omitted the dummies in the tables of our test statistics. The full test statistics are provided in the annex (Table A2-A5). 
variable year symbolises the autonomous technical progress. With the exception of 'imsha' all variables have the expected signs. One explanation for the positive correlation between a high share of imports in GDP and high per capita DMC may be that countries with a strong industrial basis such as Germany have higher shares of imports and exports than countries with a smaller industrial base. The reason probably lies in global production chains, where raw materials and intermediate goods are imported, domestically refined into finished products and also globally traded, i.e. re-exported.

The share of imports in GDP is also the most influential factor: an increase in the import share by $1 \%$ would raise the DMC per capita by $0.225 \%$. In contrast, the increase of final energy consumption per capita by $1 \%$ would lead to an increase in DMC by $0.177 \%$. The length of the motorway network per capita and the completed dwelling units per 1000 inhabitants have approximately the same explanation power. Finally, the variable 'year' shows, that under ceteris paribus conditions, DMC per capita would fall by $1.27 \%$ p.a. because of the autonomous technological progress.

However, the value of rho (0.52) indicates that this model is shaped by autocorrelation. As a common rule of thumb, a rho value $<0.3$ can be considered as unproblematic, and the influence of the autocorrelation can be considered low. In our case, we can infer from the high value of rho that DMC per capita is strongly influenced by the previous period. In a normal fixed-effects model (without the corrected standard error) this AR1 coefficient could be calculated and be expelled. However, any integration of DMC per capita of the previous period as an explanatory variable in the analysis is not an easy way out of this situation, since this variable would dominate the entire model and the other variables would no longer be significant. 
Table 2 shows the test statistics for the full panel of the EU-27 for the period between 1992 and 2000. It reveals slightly other variables as explanatory variables compared to the EU-15. Here again all variables are within the 5\% significance level. With exception of EU patents per 1 million inhabitants (pat_eu), all the variables have the expected sign. However, the influence of the patent variable is comparatively low.

\section{Table 2: Drivers for Domestic Material Consumption per capita Test statistics for EU-27, 1992-2000}

\begin{tabular}{lc} 
DMC per cap for EU27 & $1992-2000$ \\
\hline pop & $-0,739$ \\
& $(0,419)$ \\
con_rate & $0,259^{* * *}$ \\
& $(0,045)$ \\
gva_ind_share & $0,1888^{* *}$ \\
& $(0,087)$ \\
labprod_con & $0,153^{* * *}$ \\
& $(0,036)$ \\
pat_eu & $0,039^{* * *}$ \\
& $(0,013)$ \\
fec_cap & $0,439^{* * *}$ \\
& $(0,101)$ \\
year & $-0,006^{* *}$ \\
& $(0,003)$ \\
& \\
\hline \multirow{2}{*}{$\mathrm{N}$} & 186 \\
Groups & 27 \\
rho & 0,142 \\
\hline
\end{tabular}

Notes: Best-fit model with panel corerected standard errors (PCSE), country dummies and common AR(1)-process. Standard errors in brackets. ${ }^{* * *}$ significant at the $1 \%$-level; ${ }^{* *}$ significant at the $5 \%$-level; ${ }^{*}$ significant at the $10 \%-l e v e l$.

Population density (pop) has the strongest influence on DMC per capita. An increase in population density by $1 \%$ would lead to a reduction of DMC by $0.74 \%$. However any increase in population density by $1 \%$ would be ambitious. This would require a very significant increase of population in absolute numbers, which in turn would explain the high relevance of this variable.

The high impact of final energy consumption per capita (fec_cap) on DMC per capita is surprising in comparison to the EU-15 panel: if energy consumption per capita were increased by $1 \%$, DMC per capita would rise to at least $0.44 \%$. Probably this reflects the 
energy mix in those countries, which is based on fossil energy sources - mainly coal. Thus higher energy consumption influences DMC more directly then in e.g. France and Italy (high proportion of nuclear power ${ }^{10}$ ) or the Scandinavian countries and Austria (large share of hydro energy).

The share of employees in the construction sector in total employment (con_rate), the share of gross value added of the industrial sector in GDP (gva_ind_share) and the labour productivity in construction sector (labprod_con) halso have a high explanatory power on DMC per capita. For all three variables, the correlation with DMC per capita is positive. Again, the variable year explains the influence of an autonomous technological progress on DMC per capita under ceteris paribus conditions. The shorter time series leads, on the one hand, to a lower value of the variable year, but, on the other hand, reduces or eliminates our problem with first order autocorrelation. The rho value is 0.142 , considerably below the critical mark of 0.3 .

In a next step the drivers for material intensity (DMC_int) were analysed.

10 In the case of Italy, the energy from nuclear power sources is imported from France. Italy has no domestic nuclear power station. 
Table 3: $\quad$ Drivers for material intensity (DMC in kg per 1000 US\$ ppp).

Test statistics for EU-15, 1980-2000

Material Intensity for EU15 1980-2000

\begin{tabular}{lc} 
ind_rate & $1,171^{\star * *}$ \\
& $(0,158)$ \\
imcap & $-0,202^{* \star *}$ \\
& $(0,047)$ \\
labprod_ind & $0,256^{\star *}$ \\
& $(0,102)$ \\
gva_con_share & $0,341^{* * *}$ \\
& $(0,078)$ \\
pop & $0,712^{* *}$ \\
& $(0,340)$ \\
pes_cap & $-0,101^{* \star}$ \\
& $(0,039)$ \\
dwell & $0,408^{* *}$ \\
& $(0,162)$ \\
con_rate & $-0,192^{* *}$ \\
& $(0,090)$ \\
& \\
\hline \multirow{2}{*}{ N } & 171 \\
Groups & 12 \\
rho & 0,545 \\
\hline
\end{tabular}

Notes: Best-fit model with panel corerected standard errors (PCSE), country dummies and common AR(1)-process

Standard errors in brackets. ${ }^{* * *}$ significant at the $1 \%$-level; ${ }^{* *}$ significant at the $5 \%$-level; ${ }^{*}$ significant at the $10 \%$-level.

Because material intensity and productivity is a ratio of GDP and DMC, it is not surprising that in the univariate regression analysis GDP in US\$ in PPP out of all variables has the highest correlation with resource intensity. For this reason we exclude GDP in US\$ PPP in our multivariate regression analysis as an explanatory variable. As with the analysis of the drivers of material consumption per capita, the results of the two panels are different with regard to their explanatory variables.

The material intensity of the EU-15 countries from 1980 to 2000 are explained by the share of employment in the manufacturing sector in total employment (ind_rate), imports per capita (imcap), labour productivity in the industrial sector (labprod_ind), the share of the construction sector in GDP (gva_con_share), population density (pop), primary energy generation per capita (pes_cap), dwelling stock (dwell) and the share of employees in the construction sector in total employment (con_rate). 
All variables are logarithmised, so that a direct ranking of the importance of each variable on the change of resource intensity can be determined. A $1 \%$ increase in the share of employment in the manufacturing sector in total employment would result in a $1.17 \%$ increase of the material intensity or, conversely, to a decline of material productivity. This result probably captures the fact that direct material consumption within the industrial sector is significantly more resource intensive than in the service sector. Analyses with input-output methods (Acosta-Fernández et al. [1]) however indicate that service sectors also use more resources than usually assumed because of their interlinkages with upstream sectors.

Higher imports per capita, on the other hand, lead to a declining material intensity and would therefore support the hypothesis that a high proportion in foreign trade would be an indication for open economies with very high competitive pressure. This competitive pressure seems to lead to a more efficient use of resources and energy. In contrast, an increase in labour productivity in the industrial sector would result in a decline in material productivity. A tentative explanation for such apparently paradoxical results is probably the fact that highly productive industrial sectors are also resource-intensive sectors. Alongside with high shares of GVA and employment levels this leads to a high level of resource consumption originating from high volumes of industrial production. This pure quantities and growth effect is likely to be at the expense of the development of the material productivity. Seen from another angle, it may lead to acknowledging the potential for increasing material productivity with labour augmentation (Hödl 2009 [31]; Bleischwitz [7]).

Other variables such as 'con_rate', 'gva_con_share' and 'pop' show surprising signs that cannot be easily justified. It is not quite obvious why a higher population density 
seems to lead to a decline in material productivity. Intuitively, one would rather expect the opposite: a low population density usually should require higher expenditures of materials for infrastructure systems per capita. The univariate regression analysis between material intensity and population density then delivers a negative sign for the coefficients. The different sign between the proportion of employees in the construction sector in total employment on the one hand and the gross value added of the construction sector on the other hand is also not easy to explain. One would expect that both have an equal sign. Here too, the sign for 'con_rate' changes from a positive sign in the univariate investigation to a negative sign when integrated into a multivariate model with other variables. Perhaps the change in the sign results from the interplay between the variables of the industrial sector and the construction sector.

The negative sign for the primary energy generation per capita is probably due to the high proportion of non-fossil energy sources, mainly hydropower and nuclear power in the energy mix in many EU-15 countries. The positive correlation between the dwelling stock and the material intensity indicates that a huge dwelling stock requires a lot of construction minerals for maintaining this stock.

As with the EU-15 regarding DMC per capita as an explanatory variable, the results also reveal problems with strong autocorrelation in the test statistics for drivers of material intensity in the EU-15. 
Table 4: $\quad$ Drivers for material intensity (DMC in kg per 1000 US\$ ppp).

Test statistic for EU-27, 1992-2000

Material Intensity for EU27 1992-2000

\begin{tabular}{lc}
\hline ind_rate & $0,336^{\star \star}$ \\
& $(0,163)$ \\
gva_ser_share & $-1,347^{\star \star \star}$ \\
& $(0,242)$ \\
imcap & $-0,148^{\star \star \star}$ \\
& $(0,047)$ \\
dw_com & $0,044^{*}$ \\
& $(0,026)$ \\
rail_cap & $-0,520^{\star \star *}$ \\
& $(0,152)$ \\
labprod_ind & $-0,265^{\star \star}$ \\
& $(0,104)$ \\
pes_cap & $0,078^{*}$ \\
& $(0,045)$ \\
& \\
\hline \multirow{2}{*}{ N } & 159 \\
Groups & 22 \\
rho & 0,209 \\
\hline
\end{tabular}

Notes: Best-fit model with panel corerected standard errors (PCSE), country dummies and common AR(1)-process. Standard errors in brackets. ${ }^{* * *}$ significant at the $1 \%$-level; ${ }^{\star *}$ significant at the $5 \%$-level; ${ }^{*}$ significant at the $10 \%-l e v e l$.

For the full panel of EU-27 countries in 1992-2000 the following variables have been identified as crucial variables: the share of employment in the manufacturing sector in the total number of employees (ind_rate), the share of the services sector in GDP (gva_ser_share), the imports per capita (imcap), the number of completed dwelling units per 1 million inhabitants (dw_com), the length of the rail network (rail_cap), labour productivity in the industrial sector (labprod_ind) and per capita primary energy generation (pes_cap). Thus many variables in both the EU-15 panel and EU-27 panel with the shorter time series are significant. However, 'labprod_ind' and 'pes_cap' have changed their signs compared to the EU-15 panel. This suggests that the total energy mix in the EU-27 is based more on fossil fuels than in the EU-15 countries and thus an increase in primary energy generation per capita leads to declining material productivity in the total panel of the EU-27. On the other hand, a rising labour productivity in the industrial sector in the new member states is often the result of new investments, often accompanied by foreign direct investments (FDI), which improves the capital stock in a way that the new equipment is significantly more resource- 
efficient than previous capital. As a result, the labour productivity of the industrial sector is negatively correlated with material intensity - at least for a transition period.

The strongest correlation can be identified between the share of the service sector in GDP and material intensity. An increase in the share of the tertiary sector in GDP by $1 \%$ leads to a reduction of resource intensity by $1.347 \%$. 


\section{Conclusions}

The regression analysis undertaken for our sample of countries reveals interesting results and a number of conclusions can be drawn.

Energy use has a high significance for resource use per capita as well as for material productivity. This confirms analysis undertaken by Acosta-Fernández et al. ([1]) for Germany, and also indicates the relevance of energy issues for any system innovation and change: fostering energy efficiency on all system levels (production, distribution, use) will probably also lead to increases in resource productivity. This finding also indicates the relevance of more specific socio-economic drivers, which are subsequent to energy use and behaviour.

The construction sector and its industries have a high impact on both resource use and material productivity; this is partly due to the indicator DMC that is usually dominated by construction minerals (Bleischwitz\&Bahn-Walkowiak [11]). However the results of our regression analysis confirm the relevance of related drivers: maintenance of existing buildings and innovation towards multifunctional building envelopes turn out to be a key to improving resource productivity (Bringezu/Bleischwitz, chapter 4, [18]). Seen from another angle, it is very likely that the investments in new roads and dwellings which have been undertaken in the context of the current financial crisis will lower the resource productivity in the near future.

Mobility variables are also of critical importance for resource use and resource productivity, especially as future studies will account for 'hidden flows' and 'ecological ruck- 
sacks' of metals. Although only one of the mobility variables (length of networks) has turned out to be part of the best-fit-models in this study, one may refer to related findings (Steger/Bleischwitz [50]) which reveal a high relevance of car possession as a driver resources use. Mobility patterns will thus have to remain on the agenda for future research with better data. Our approach can be seen as a starting point for including socio-economic data that are able to capture consumption and behavioural patterns (Vergragt/Brown [55]).

The three cross-cutting drivers identified are linked to main areas of public policy and sustainable consumption and production: energy is a key issue of climate change and low carbon society efforts; construction is close to local planning and peoples' aspirations for housing; roads are under member states and (in the new member states via cofinancing through regional funds) EU responsibility. This means that our findings generally support cooperative approaches with stakeholder involvement and pose attention to policy consistency, incentives for strategic $R \& D$ and changing preferences.

The service sector also has an influence on the resource intensity of economies. However, there are open questions with regard to indirect flows of resources within an economy. The method of regression analysis is not especially suited to deal with this problem. Interestingly however, our results are in line with findings from input-output analysis (Acosta-Fernández et al. [1]) as well as life cycle analysis (Tukker et al. [53]).

Another open issue relates to international trade. Our findings are quite mixed, with a large share of imports being less favourable for DMC consumption in the case of the EU-15 and more favourable for increasing resource productivity for the EU-27. This 
suggests more detailed analysis at the level of industries in order to arrive at better findings, and certainly more in-depth analysis on international trade.

Though these findings are encouraging for guiding future sustainability efforts, overall dynamics will need further research. For instance, stationarity tests need to be conducted. Given the difficulties with often non-stationary macroeconomic time series, methods of co-integration or vector error correction models (VECM) could be fruitful for our analysis on the causality between drivers and resource use and resource productivity. In addition, our cross-country analysis of drivers will need to be complemented by country-specific and industry-specific analysis. The good news here is that this can be done with a coherent methodology (i.e. regression analysis). This would deepen understanding on the relevance of cross-cutting drivers in relation to specific drivers. Secondly, there are open questions regarding labour productivity and resource productivity. The current data situation on labour productivity on the basis of number of employees cannot capture the working hour differences between countries. Better time series data on working hours across countries and sectors will help to improve the quality of research in future, and help to tackle the question of drivers for total factor productivity growth. This is important since a more detailed analysis will likely offer explanations for either synergies between labour and resource productivity or potential for any labour augmenting progress alongside with increasing resource productivity. Micro-oriented data sources such as the EU Community Innovation Survey can be used for that purpose.

Since the database used in this article ends in the year 2000, the sharp increase of prices for raw materials and energy fuels recently has not been incorporated in our analysis. An update of our database will be addressed this year. 
To conclude, our analysis also shows that results depend at least partly on the length and quality of the time series as well as on the chosen country panel. Further detailed analysis with longer time series, a broader country panel and complementary countryspecific analysis is required to deepen the understanding of drivers.

\section{Acknowledgements}

Research on this paper has been supported by a project conducted on behalf of the European Commission (DG ENV, Project ENV.G.1/ETU/2007/0041). The authors wish to thank Stefan Bringezu, Bettina Bahn-Walkowiak, Mathias Onischka, Oliver Röder, Meghan O'Brien and Werner Bosmans as well as the participants of a session at the Utrecht Conference ISDR 2009 at the 2009 Wuppertal Colloquium on „Sustainable Growth, Resource Productivity and Sustainable Industrial Policy" for useful comments. 


\section{Appendix}

Table A1: Overview of variables and expected signs

\begin{tabular}{|c|c|c|c|}
\hline Variable & Description & Unit of measurment & Expected Sign \\
\hline DMCcap & Direct Material Consumtion per cap & in Tonnes per cap & \\
\hline DMC_int & Direct Material Consumtion per 1000 US $\$$ in ppp & in $\mathrm{kg}$ per 1000 US\$ in ppp & \\
\hline pop & Population density & in persons per $\mathrm{km}^{2}$ & - \\
\hline unemp & Unemployment rate & in $\%$ of total labor force & + \\
\hline lab & labour force participation & in $\%$ of total population & ? \\
\hline agr_rate & $\begin{array}{l}\text { share of employees in the agriculture sector on total } \\
\text { employess }\end{array}$ & in \% & - \\
\hline ind rate & $\begin{array}{l}\text { share of employees in the industry sector on total } \\
\text { employess }\end{array}$ & in \% & + \\
\hline con_rate & $\begin{array}{l}\text { share of employees in the construction sector on } \\
\text { total employess }\end{array}$ & in \% & + \\
\hline ser_rate & $\begin{array}{l}\text { share of employees in the service sector on total } \\
\text { employess }\end{array}$ & in $\%$ & - \\
\hline GDPcap_ppp & $\begin{array}{l}\text { Gross Domestic Product in Purchasing Power } \\
\text { Parity per cap }\end{array}$ & in US\$ per cap EKS & + \\
\hline GDPcap_con & Gross Domestic Product in real prices per cap & in Euro per cap & + \\
\hline inv_cap & Gross fixed capital formation constant per cap & in Euro per cap & + \\
\hline con_cap & $\begin{array}{l}\text { Consumption expenditure of privat households per } \\
\text { cap }\end{array}$ & in Euro per cap & + \\
\hline con share & $\begin{array}{l}\text { share of consumption expenditure of private } \\
\text { hauseholds on GDP }\end{array}$ & in $\%$ of GDP & + \\
\hline gva agr_cap & Gross Value Added agricultural sector per cap & in Euro (constant prices) per cap & - \\
\hline gva_ind_cap & Gross Value Added industry sector per cap & in Euro (constant prices) per cap & + \\
\hline gva_con_cap & Gross Value Added construction sector per cap & in Euro (constant prices) per cap & + \\
\hline gva_ser_cap & Gross Value Added service sector per cap & in Euro (constant prices) per cap & - \\
\hline gva_agr_share & share of GVA agricultural sector on total GVA & in \% & - \\
\hline gva_ind_share & share of GVA industry sector on total GVA & in $\%$ & + \\
\hline gva_cap_share & share of GVA construction sector on total GVA & in $\%$ & + \\
\hline gva_ser_share & share of GVA service sector on total GVA & in $\%$ & - \\
\hline labprod_agr & labour productivity agricultural sector per employee & in Euro (constant prices) per employee & ? \\
\hline labprod_ind & labour productivity industry sector per employee & in Euro (constant prices) per employee & ? \\
\hline labprod_con & $\begin{array}{l}\text { labour productivity construction sector per } \\
\text { employee }\end{array}$ & in Euro (constant prices) per employee & ? \\
\hline labprod_ser & labour productivity service sector per employee & in Euro (constant prices) per employee & ? \\
\hline pexp_edu & public expenditure on education & in \% of GDP & - \\
\hline exp_RuD & expenditure in R\&D & in \% of GDP & - \\
\hline pat_eu & $\begin{array}{l}\text { patent application in the European Patent Office } \\
\text { (EPA) }\end{array}$ & per Mio. Persons & - \\
\hline pat_us & $\begin{array}{l}\text { patent application in the United States Patent and } \\
\text { Trademark Office (USPTO) }\end{array}$ & per Mio. Persons & - \\
\hline tert_deg & $\begin{array}{l}\text { university degrees in natural \&engineering science } \\
\text { per } 1000 \text { cap in the age of } 20-29\end{array}$ & in $\%$ of population, age $20-29$ & - \\
\hline excap & Exporte per cap & in Euro & ? \\
\hline exsha & share of Exports on GDP & in $\%$ of GDP & - \\
\hline imcap & Importe per cap & in Euro & ? \\
\hline imsha & share of Imports on GDP & in $\%$ of GDP & - \\
\hline
\end{tabular}




\begin{tabular}{|c|c|c|c|}
\hline Variable & Description & Unit of measurment & Expected Sign \\
\hline gfcf_cap_mach & $\begin{array}{l}\text { Gross fixed capital formation in Metal products and } \\
\text { machinery }\end{array}$ & in Euro (constant prices) per cap & + \\
\hline gfcf_cap_tran & $\begin{array}{l}\text { Gross fixed capital formation in Transport } \\
\text { equipment }\end{array}$ & in Euro (constant prices) per cap & + \\
\hline gfcf_cap_hous & $\begin{array}{l}\text { Gross fixed capital formation in Construction work } \\
\text { housing }\end{array}$ & in Euro (constant prices) per cap & + \\
\hline gfcf_cap_con & $\begin{array}{l}\text { Gross fixed capital formation in Construction work } \\
\text { other constructions }\end{array}$ & in Euro (constant prices) per cap & + \\
\hline gfcf_cap_oth & Gross fixed capital formation in Other products & in Euro (constant prices) per cap & + \\
\hline gfcf_sha_mach & $\begin{array}{l}\text { share of Gross fixed capital formation in Metal } \\
\text { products and machinery on GDP }\end{array}$ & in \% of GDP & + \\
\hline gfcf_sha_tran & $\begin{array}{l}\text { share Gross fixed capital formation in Transport } \\
\text { equipment on GDP }\end{array}$ & in \% of GDP & + \\
\hline gff__sha_hous & $\begin{array}{l}\text { share Gross fixed capital formation in Construction } \\
\text { work housing onGDP }\end{array}$ & in \% of GDP & + \\
\hline gfcf_sha_con & $\begin{array}{l}\text { share Gross fixed capital formation in Construction } \\
\text { work on GDP }\end{array}$ & in \% of GDP & + \\
\hline gfff_sha_con_total & $\begin{array}{l}\text { share Gross fixed capital formation in Construction } \\
\text { work other constructions on GDP }\end{array}$ & in $\%$ of GDP & + \\
\hline gfcf_sha_oth & $\begin{array}{l}\text { share Gross fixed capital formation in Other } \\
\text { products on total gross fixed capital formation }\end{array}$ & in \% of GDP & + \\
\hline heat & $\begin{array}{l}\text { Heating requierements (yearly undercut of an } \\
\text { average temp. in cumulated degrees) }\end{array}$ & $\begin{array}{l}\text { average daily difference between medium } \\
\text { temperature and } 18^{\circ} \mathrm{C}\end{array}$ & + \\
\hline $\mathrm{cool}$ & $\begin{array}{l}\text { Cooling requierements (yearly undercut of an } \\
\text { average temp. in cumulated degrees) }\end{array}$ & $\begin{array}{l}\text { average daily difference between medium } \\
\text { temperature and } 18^{\circ} \mathrm{C}\end{array}$ & + \\
\hline waste_coll & municipal solid waste (collected) per cap & in $\mathrm{kg}$ per cap/year & $?$ \\
\hline waste_dep & municipal solid waste (landfilled) per cap & in $\mathrm{kg}$ per cap/year & ? \\
\hline waste_burn & municipal solid waste (burned) per cap & in $\mathrm{kg}$ per cap/year & $?$ \\
\hline renew & share renewable energy on total energy use & in $\%$ of total energy use & - \\
\hline ene_inten & Energy intensity & $\begin{array}{l}\text { gross energy consumption vs GDP) kg } \\
\text { (oe) per } 1000 \text { Euro }\end{array}$ & - \\
\hline pes_cap & Primary Energy Generation per cap & in toe per cap & + \\
\hline gec_cap & Gross Domestic Energy Use per cap & in toe per cap & + \\
\hline fec_cap & Final Energy Consumption per cap & in toe per cap & + \\
\hline fec_ind_cap & Final Energy Consumption Industry per cap & in toe per cap & + \\
\hline fec_house_cap & $\begin{array}{l}\text { Final Energy Consumption private households per } \\
\text { cap }\end{array}$ & in toe per cap & + \\
\hline price_sup & price of petroleum super (incl. tax) & in Euro per 1000 liter & - \\
\hline price_unlead & price of petroleum unleaded (incl. tax) & in Euro per 1000 liter & - \\
\hline price_die & price of petroleum diesel (incl. tax) & in Euro per 1000 liter & - \\
\hline price_light & price of petroleum light oil (incl. tax) & in Euro per 1000 liter & - \\
\hline dwell & Dwelling Stock & Dwellings per 1000 capita & + \\
\hline tkmcap & transport-km per cap & in tkm per cap & + \\
\hline pkmcap & passenger kilometers per cap & in pkm per cap & + \\
\hline mw_cap & motorways per cap & in meters per cap & + \\
\hline roadscap & streets per cap (without motorways) & in meters per cap & + \\
\hline rail_cap & railway per cap & in meters per cap & + \\
\hline cars & car possession & numbers of cars per 1000 cap & + \\
\hline dw_com & dwellings completed & per 1000 cap & + \\
\hline
\end{tabular}




\section{Fig A1: $\quad$ Correlation-matrix EU-15 1980-2000, limited variables}

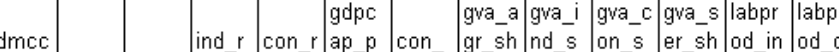

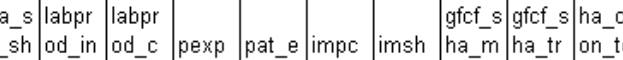
gfcf $s$
ha_c
on_to

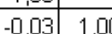

dmccap

\begin{tabular}{l|r|r|r|}
\hline pop & $-0,03$ & 1,00 & \\
\hline lab & 0,25 & 0,59 & 1,00 \\
\hline La
\end{tabular}

\begin{tabular}{l|c|c|c|c|}
\hline lab rate & 0,06 & $-0,66$ & $-0,16$ & 1,00 \\
\hline cond & 0,05 & $-0,46$ & $-0,53$ & 0,08 \\
\hline
\end{tabular}

\begin{tabular}{l|c|c|c|c|c|}
\hline con rate & 0,08 & $-0,46$ & $-0,53$ & 0,68 & 1,00 \\
\hline
\end{tabular}

\begin{tabular}{l|r|r|r|r|r|r|}
\hline gdpcap ppp & 0,27 & 0,54 & 0,65 & $-0,50$ & $-0,69$ & 1,00 \\
\hline
\end{tabular}

\begin{tabular}{l|c|c|c|c|c|c|c|c|}
\hline con share & $-0,48$ & $-0,54$ & $-0,39$ & 0,31 & 0,14 & $-0,66$ & 1,00 \\
\hline
\end{tabular}

\begin{tabular}{l|c|c|c|c|c|c|c|c|c|}
\hline gva agr share & $-0,09$ & $-0,38$ & $-0,71$ & $-0,06$ & 0,38 & $-0,75$ & 0,053 & 1,00
\end{tabular}

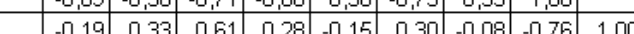

\begin{tabular}{l|c|c|c|c|c|c|c|c|c|c|c|}
\hline con share & $-0,07$ & $-0,35$ & $-0,63$ & 0,45 & 0,84 & $-0,80$ & 0,38 & 0,56 & $-0,16$ & 1,00
\end{tabular}

\begin{tabular}{l|lllll|l|l|l|l|l|l|l|l|l} 
gva_ser_share & 0,24 & 0,21 & 0,32 & $-0,56$ & $-0,74$ & 0,71 & $-0,37$ & $-0,26$ & $-0,30$ & $-0,86$ & 1,00 \\
\hline
\end{tabular}

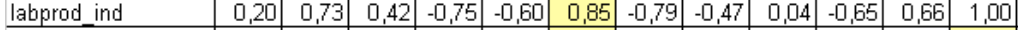

\begin{tabular}{llllllllllllllll}
\hline labprod_con & 0,25 & 0,49 & 0,43 & $-0,58$ & $-0,74$ & 0,89 & $-0,61$ & $-0,62$ & 0,15 & $-0,70$ & 0,72 & 0,83 & 1,00 \\
\hline
\end{tabular}

\begin{tabular}{llllllllllllllllll}
\hline pexp_edu & 0,51 & 0,02 & 0,49 & 0,10 & $-0,22$ & 0,54 & $-0,65$ & $-0,56$ & 0,08 & $-0,61$ & 0,54 & 0,38 & 0,44 & 1,00 \\
\hline
\end{tabular}

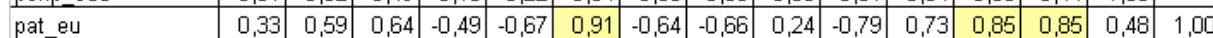

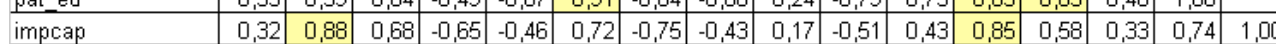

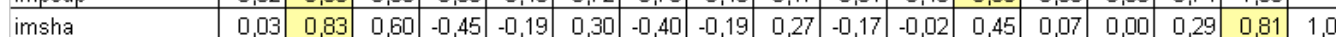

\begin{tabular}{l|c|c|c|c|c|c|c|c|c|c|c|c|c|c|c|c|c|c|}
\hline gfcf sha mach & $-0,20$ & 0,11 & 0,59 & 0,10 & $-0,36$ & 0,32 & 0,27 & $-0,48$ & 0,58 & $-0,38$ & 0,09 & $-0,08$ & 0,04 & 0,02 & 0,22 & 0,09 & 0,23 & 1,00
\end{tabular}

\begin{tabular}{l|c|c|c|c|c|c|c|c|c|c|c|c|c|c|c|c|c|c|c|}
\hline gfcf_sha_tran & 0,28 & 0,46 & 0,40 & $-0,22$ & 0,07 & 0,13 & $-0,29$ & 0,02 & 0,00 & $-0,08$ & 0,02 & 0,23 & $-0,15$ & 0,15 & 0,14 & 0,57 & 0,78 & 0,17 & 1,00 \\
\hline
\end{tabular}

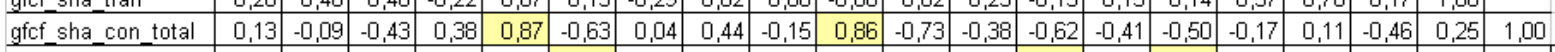

\begin{tabular}{l|l|l|l|l|l|l|l|l|l|l|l|l|l|l|l|l|l|l|l|l|l|l|l} 
heat & 0,34 & 0,70 & 0,79 & $-0,52$ & $-0,74$ & 0,88 & $-0,62$ & $-0,68$ & 0,32 & $-0,77$ & 0,67 & 0,80 & 0,84 & 0,51 & 0,93 & 0,79 & 0,41 & 0,26 & 0,18 & $-0,55$ & 1,00 \\
\hline
\end{tabular}

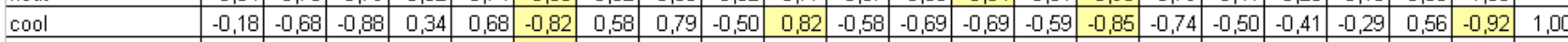

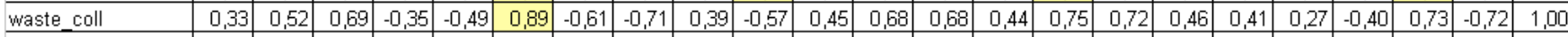

\begin{tabular}{llllllllllllllllllllllllllllll}
\hline renew & $-0,02$ & $-0,76$ & $-0,56$ & 0,66 & 0,66 & $-0,55$ & 0,18 & 0,33 & $-0,31$ & 0,39 & $-0,31$ & $-0,56$ & $-0,58$ & 0,11 & $-0,58$ & $-0,64$ & $-0,49$ & $-0,30$ & $-0,18$ & 0,34 & $-0,72$ & 0,57 & $-0,49$ & 1,00 & \\
\hline
\end{tabular}

\begin{tabular}{llllllllll|l|l|l|l|l|l|l|l|l|l|l|l|l|l|l|l|l}
\hline pes_cap & $-0,07$ & 0,83 & 0,72 & $-0,69$ & $-0,82$ & 0,76 & $-0,39$ & $-0,58$ & 0,40 & $-0,69$ & 0,51 & 0,74 & 0,72 & 0,19 & 0,72 & 0,76 & 0,57 & 0,40 & 0,20 & $-0,60$ & 0,85 & $-0,82$ & 0,64 & $-0,85$ & 1,00 \\
\hline
\end{tabular}

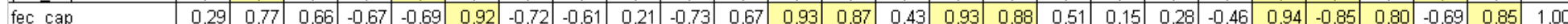

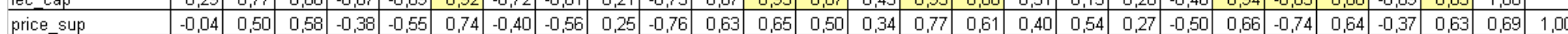

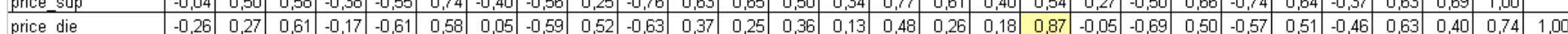

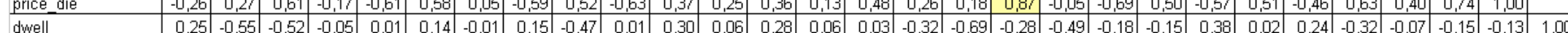

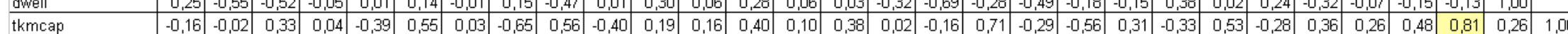

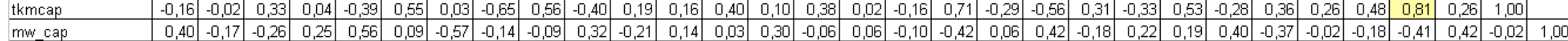

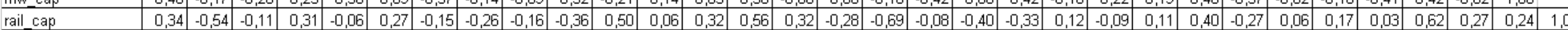

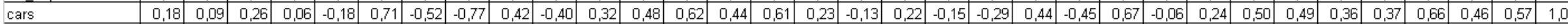

diwe com

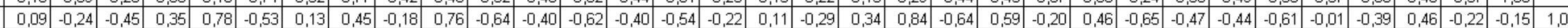




\section{Fig A2: Correlation-matrix EU-27 1992-2000, limited variables}

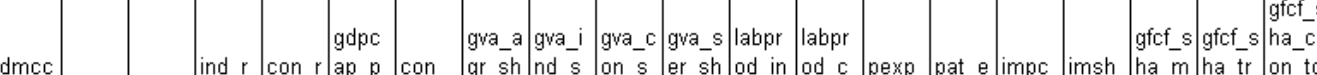

ap pop lab ate

\begin{tabular}{|c|c|c|c|c|c|c|c|c|c|c|c|c|c|c|c|c|c|c|c|c|c|c|c|c|c|c|c|c|c|c|c|c|c|c|}
\hline & ap & pop & lab & ate & ate & pp & share & are & hare & hare & are & d & $o^{-}$ & _edu & $u^{p a t}{ }^{-}$ & ap & a & ackm & $a^{1+1}$ & $\mathrm{tal}^{0}=\mathrm{h}$ & heat & cool & coll & renew & cap - & $a^{-}$ & sup & die & dwell & ap & ap -6 & ap & cars & $\begin{array}{l}\mathrm{om}^{2}-\mathrm{c} \\
\mathrm{m}\end{array}$ \\
\hline dmccap & 1,00 & & & & & & & & & & & & & & & & & & & & & & & & & & & & & & & & & \\
\hline pop & $-0,26$ & 1,00 & & & & & & & & & & & & & & & & & & & & & & & & & & & & & & & & \\
\hline $\mathrm{ab}$ & 0,44 & \begin{tabular}{|l|l|}
0,15 \\
\end{tabular} & 1,00 & & & & & & & & & & & & & & & & & & & & & & & & & & & & & & & \\
\hline ind_rate & 0,06 & \begin{tabular}{|l|l|}
$-0,42$ \\
\end{tabular} & $-0,27$ & 1,00 & & & & & & & & & & & & & & & & & & & & & & & & & & & & & & \\
\hline con_rate & $-0,05$ & $-0,37$ & $-0,35$ & 0,57 & \begin{tabular}{|l|}
1,00 \\
\end{tabular} & & & & & & & & & & & & & & & & & & & & & & & & & & & & & \\
\hline gdpcap_ppp & 0,41 & 0,37 & 0,62 & $-0,62$ & $-0,62$ & 1,00 & & & & & & & & & & & & & & & & & & & & & & & & & & & & \\
\hline con_share & $-0,57$ & $-0,35$ & $-0,39$ & 0,43 & 0,26 & $-0,68$ & 1,00 & & & & & & & & & & & & & & & & & & & & & & & & & & & \\
\hline gva_agr_share & $-0,21$ & $-0,34$ & $-0,40$ & 0,00 & 0,34 & \begin{tabular}{|l|l|}
$-0,59$ \\
\end{tabular} & 0,33 & $1,00 \mid$ & & & & & & & & & & & & & & & & & & & & & & & & & & \\
\hline gva ind share & $-0,14$ & \begin{tabular}{|l|}
0,07 \\
\end{tabular} & 0,11 & 0,23 & 0,02 & \begin{tabular}{|c|}
$-0,03$ \\
\end{tabular} & 0,20 & \begin{tabular}{|l|}
$-0,62$ \\
\end{tabular} & 1,00 & & & & & & & & & & & & & & & & & & & & & & & & & \\
\hline gva_con_share & $-0,11$ & $-0,34$ & $-0,23$ & 0,24 & 0,80 & $-0,50$ & 0,37 & \begin{tabular}{|l|}
0,31 \\
\end{tabular} & 0,12 & 1,00 & & & & & & & & & & & & & & & & & & & & & & & & \\
\hline gva_ser_share & 0,29 & 0,34 & 0,25 & $-0,35$ & $-0,69$ & 0,64 & $-0,49$ & $-0,21$ & $-0,52$ & \begin{tabular}{|l|}
$-0,82$ \\
\end{tabular} & 1,00 & & & & & & & & & & & & & & & & & & & & & & & \\
\hline labprod ind & 0,23 & 0,45 & 0 & $-0,81$ & $-0,48$ & 0,82 & $-0,73$ & $|-0,44|$ & 0,06 & \begin{tabular}{|c|}
$-0,28$ \\
\end{tabular} & \begin{tabular}{|l|}
0,37 \\
\end{tabular} & 1,00 & & & & & & & & & & & & & & & & & & & & & & \\
\hline labprod_con & 0,46 & 0,21 & 0,38 & $-0,53$ & $-0,50$ & 0,80 & $-0,56$ & $-0,62$ & 0,10 & \begin{tabular}{|c|}
$-0,20$ \\
\end{tabular} & 0,41 & 0,79 & 1,00 & & & & & & & & & & & & & & & & & & & & & \\
\hline pexp_edu & 0,38 & 0,26 & 0,43 & $-0,31$ & $-0,58$ & 0,74 & $-0,59$ & $-0,66$ & 0,25 & \begin{tabular}{|l|}
$-0,62$ \\
\end{tabular} & 0,54 & 0,66 & \begin{tabular}{|l|}
0,65 \\
\end{tabular} & 1,00 & & & & & & & & & & & & & & & & & & & & \\
\hline pat_eu & 0,43 & 0,30 & 0,56 & $-0,26$ & $-0,37$ & 0,73 & $-0,58$ & $-0,59$ & 0,23 & \begin{tabular}{|l|l|}
$-0,44$ \\
\end{tabular} & 0,42 & 0,63 & 0,56 & 0,86 & 1,00 & & & & & & & & & & & & & & & & & & & \\
\hline impcap & 0,39 & 0,56 & 0,44 & $-0,62$ & $-0,41$ & 0,74 & $-0,71$ & $-0,40$ & $-0,05$ & $-0,28$ & \begin{tabular}{|l|}
0,44 \\
\end{tabular} & 0,80 & 0,67 & 0,43 & 0,53 & 1,00 & & & & & & & & & & & & & & & & & & \\
\hline imsha & 0,04 & 0,65 & 0,20 & $-0,53$ & $-0,29$ & 0,41 & $-0,42$ & $-0,25$ & 0,04 & $-0,16$ & 0,20 & 0,57 & 0,34 & 0,08 & 0,19 & 0,86 & 1,00 & & & & & & & & & & & & & & & & & \\
\hline gfcf_sha_mach & 0,07 & 0,13 & 0,29 & $-0,04$ & $-0,41$ & 0,34 & 0,11 & $-0,55$ & 0,43 & $-0,30$ & \begin{tabular}{|l|}
0,15 \\
\end{tabular} & 0,13 & 0,26 & 0,21 & 0,22 & \begin{tabular}{l|l|}
0,37 \\
\end{tabular} & \begin{tabular}{|l|}
0,45 \\
\end{tabular} & 1,00 & & & & & & & & & & & & & & & & \\
\hline gfcf sha _tran & 0,22 & 0,31 & 0,50 & $-0,32$ & $-0,01$ & 0,39 & $-0,43$ & 0,07 & $-0,35$ & $-0,12$ & \begin{tabular}{|l|}
0,28 \\
\end{tabular} & 0,30 & 0,05 & 0,00 & 0,19 & 0,53 & \begin{tabular}{|l|}
0,51 \\
\end{tabular} & 0,08 & 1,00 & & & & & & & & & & & & & & & \\
\hline gfcf sha con total & 0,01 & $-0,07$ & $-0,04$ & 0,29 & 0,83 & $-0,34$ & 0,10 & 0,16 & 0,09 & 0,84 & \begin{tabular}{|c|}
$-0,63$ \\
\end{tabular} & $-0,16$ & $-0,19$ & $-0,38$ & $-0,10$ & $-0,14$ & $|-0,10|$ & $-0,42$ & 0,14 & 1,00 & & & & & & & & & & & & & & \\
\hline heat & 0,62 & 0,30 & 0,70 & $-0,44$ & $-0,57$ & 0,82 & $-0,67$ & $-0,65$ & 0,20 & \begin{tabular}{|l|}
$-0,42$ \\
\end{tabular} & \begin{tabular}{|l|}
0,46 \\
\end{tabular} & 0,74 & 0,81 & 0,81 & 0,80 & 0,71 & \begin{tabular}{|l|}
0,37 \\
\end{tabular} & 0,36 & 0,20 & $-0,24$ & 1,00 & & & & & & & & & & & & & \\
\hline cool & $-0,35$ & $-0,51$ & $-0,71$ & 0,35 & 0,68 & $-0,76$ & 0,57 & 0,73 & $-0,24$ & \begin{tabular}{|l|}
0,63 \\
\end{tabular} & \begin{tabular}{|c|}
$-0,57$ \\
\end{tabular} & $-0,61$ & \begin{tabular}{|l|l|}
$-0,62$ \\
\end{tabular} & $-0,76$ & $-0,68$ & $-0,65$ & \begin{tabular}{|l|}
$-0,46$ \\
\end{tabular} & $-0,48$ & $-0,31$ & 0,36 & $-0,86$ & 1,00 & & & & & & & & & & & & \\
\hline waste coll & 0,42 & 0,35 & 0,68 & $-0,35$ & $-0,42$ & 0,85 & $-0,57$ & $|-0,51|$ & $-0,03$ & $-0,40$ & 0,52 & 0,53 & 0,54 & 0,61 & 0,67 & 0,52 & \begin{tabular}{|l|}
0,23 \\
\end{tabular} & 0,24 & 0,45 & $\mid-0,16$ & 0,65 & $-0,65$ & 1,00 & & & & & & & & & & & \\
\hline renew & 0,21 & $-0,53$ & 0,21 & $-0,22$ & \begin{tabular}{|l|}
0,24 \\
\end{tabular} & 0,06 & $-0,05$ & 0,04 & 0,17 & \begin{tabular}{|l|}
0,52 \\
\end{tabular} & \begin{tabular}{|c|}
$-0,45$ \\
\end{tabular} & 0,29 & 0,28 & $-0,05$ & 0,00 & 0,12 & \begin{tabular}{|l|}
0,02 \\
\end{tabular} & 0,02 & \begin{tabular}{|l|}
0,03 \\
\end{tabular} & 0,32 & 0,17 & \begin{tabular}{|l|}
0,09 \\
\end{tabular} & \begin{tabular}{|l|l|}
$-0,13$ \\
\end{tabular} & 1,00 & & & & & & & & & & \\
\hline pes_cap & 0,02 & 0,49 & 0,55 & $-0,52$ & \begin{tabular}{|l|}
$-0,75$ \\
\end{tabular} & 0,60 & $-0,36$ & $-0,26$ & $-0,05$ & \begin{tabular}{|l|}
$-0,68$ \\
\end{tabular} & \begin{tabular}{|l|}
0,56 \\
\end{tabular} & 0,39 & 0,26 & 0,53 & 0,41 & 0,33 & \begin{tabular}{|l|}
0,19 \\
\end{tabular} & 0,22 & \begin{tabular}{|l|}
0,23 \\
\end{tabular} & \begin{tabular}{|c|}
$-0,58$ \\
\end{tabular} & 0,51 & \begin{tabular}{|c|} 
\\
\end{tabular} & \begin{tabular}{|l|l|}
0,61 \\
\end{tabular} & $-0,37$ & 1,00 & & & & & & & & & \\
\hline fec cap & 0,41 & 0,55 & 0,38 & $-0,56$ & $-0,62$ & 0,80 & $-0,72$ & $|-0,63|$ & 0,17 & \begin{tabular}{|l|l|}
$-0,53$ \\
\end{tabular} & \begin{tabular}{|l|}
0,54 \\
\end{tabular} & 0,84 & 0,78 & 0,79 & 0,70 & 0,82 & 0,60 & 0,35 & 0,19 & \begin{tabular}{|c|}
$-0,36$ \\
\end{tabular} & 0,86 & $-0,80$ & 0,58 & $-0,05$ & \begin{tabular}{|l|}
0,49 \\
\end{tabular} & 1,00 & & & & & & & & \\
\hline price_sup & 0,03 & 0,30 & 0,48 & $-0,40$ & $\begin{array}{l}-0,47 \\
\end{array}$ & 0,67 & $-0,34$ & $-0,36 \mid$ & $-0,04$ & \begin{tabular}{|l|}
$-0,56$ \\
\end{tabular} & \begin{tabular}{|l|}
0,54 \\
\end{tabular} & 0,50 & \begin{tabular}{|l|}
0,27 \\
\end{tabular} & 0,53 & 0,59 & \begin{tabular}{|l|}
0,44 \\
\end{tabular} & \begin{tabular}{|l|}
0,29 \\
\end{tabular} & 0,43 & 0,37 & \begin{tabular}{|l|}
$-0,36$ \\
\end{tabular} & \begin{tabular}{|l|l|}
0,46 \\
\end{tabular} & $-0,58$ & 0,57 & $-0,05$ & \begin{tabular}{|c|}
0,54 \\
\end{tabular} & \begin{tabular}{|l|}
0,45 \\
\end{tabular} & 1,00 & & & & & & & \\
\hline price_die & $-0,12$ & 0,21 & 0,44 & $-0,30$ & $-0,57$ & 0,53 & 0,05 & $|-0,44|$ & 0,22 & \begin{tabular}{|c|}
$-0,47$ \\
\end{tabular} & \begin{tabular}{|l|}
0,34 \\
\end{tabular} & 0,26 & \begin{tabular}{|l|}
0,23 \\
\end{tabular} & 0,35 & 0,35 & 0,24 & \begin{tabular}{|l|}
0,19 \\
\end{tabular} & 0,70 & 0,07 & \begin{tabular}{|l|}
$-0,50$ \\
\end{tabular} & 0,36 . & $-0,49$ & 0,45 & $-0,08$ & \begin{tabular}{|l|}
0,58 \\
\end{tabular} & 0,30 & \begin{tabular}{|l|}
0,80 \\
\end{tabular} & 1,00 & & & & & & \\
\hline dwell & 0,28 & $-0,38$ & $-0,15$ & 0,03 & \begin{tabular}{|l|}
$-0,05$ \\
\end{tabular} & 0,20 & $-0,14$ & 0,12 & $-0,30$ & \begin{tabular}{|l|l|}
$-0,22$ \\
\end{tabular} & \begin{tabular}{|l|}
0,30 \\
\end{tabular} & $-0,01$ & \begin{tabular}{|l|}
0,09 \\
\end{tabular} & 0,31 & 0,23 & $-0,27$ & \begin{tabular}{|l|l|}
$-0,59$ \\
\end{tabular} & $-0,33$ & $-0,22$ & \begin{tabular}{|l|l|}
$-0,22$ \\
\end{tabular} & 0,01 & 0,23 & 0,27 & $-0,16$ & \begin{tabular}{|l|}
0,13 \\
\end{tabular} & $-0,01$ & \begin{tabular}{|l|}
0,06 \\
\end{tabular} & $-0,02$ & 1,00 & & & & & \\
\hline tkmcap & $-0,09$ & 0,02 & 0,05 & 0,14 & \begin{tabular}{|l|}
$-0,27$ \\
\end{tabular} & 0,22 & 0,11 & \begin{tabular}{|l|}
$-0,42$ \\
\end{tabular} & 0,40 & \begin{tabular}{|l|l|}
$-0,40$ \\
\end{tabular} & \begin{tabular}{|l|}
0,15 \\
\end{tabular} & $-0,02$ & 0,01 & \begin{tabular}{l|l}
0,43 \\
\end{tabular} & 0,39 & \begin{tabular}{|l|}
$-0,21$ \\
\end{tabular} & \begin{tabular}{|l|l|}
$-0,30$ \\
\end{tabular} & 0,29 & $-0,30$ & \begin{tabular}{|l|l|}
$-0,35$ \\
\end{tabular} & 0,14 & $-0,17$ & 0,31 & $-0,34$ & 0,35 & 0,15 & 0,35 & 0,51 & 0,46 & 1,00 & & & & \\
\hline mw_cap & 0,49 & $-0,24$ & $-0,06$ & $-0,12$ & \begin{tabular}{|l|}
0,40 \\
\end{tabular} & 0,24 & $-0,55$ & \begin{tabular}{|c|}
$-0,05$ \\
\end{tabular} & \begin{tabular}{|l|}
$-0,15$ \\
\end{tabular} & \begin{tabular}{|l|}
0,37 \\
\end{tabular} & \begin{tabular}{|l|}
$-0,12$ \\
\end{tabular} & 0,36 & \begin{tabular}{|l|l|}
0,37 \\
\end{tabular} & \begin{tabular}{l|l}
0,03 \\
\end{tabular} & 0,08 & 0,32 & \begin{tabular}{|l|}
0,13 \\
\end{tabular} & $-0,22$ & \begin{tabular}{|l|}
0,20 \\
\end{tabular} & \begin{tabular}{|l|l|}
0,35 \\
\end{tabular} & \begin{tabular}{|l|l|}
0,14 \\
\end{tabular} & 0,16 & 0,17 & 0,48 & \begin{tabular}{|c|}
$-0,36$ \\
\end{tabular} & 0,18 & \begin{tabular}{|l|}
$-0,13$ \\
\end{tabular} & $-0,36$ & 0,27 & \begin{tabular}{|l|l|}
$-0,25$ \\
\end{tabular} & 1,00 & & & \\
\hline rail cap & 0,57 & $|-0,56|$ & 0,25 & 0,01 & \begin{tabular}{|l|}
$-0,03$ \\
\end{tabular} & \begin{tabular}{|l|}
0,27 \\
\end{tabular} & $-0,27$ & \begin{tabular}{|c|}
$-0,29$ \\
\end{tabular} & \begin{tabular}{|l|}
0,27 \\
\end{tabular} & \begin{tabular}{|l|}
0,01 \\
\end{tabular} & \begin{tabular}{|l|l|}
$-0,05$ \\
\end{tabular} & 0,33 & 0,45 & 0,53 & 0,48 & 0,09 & \begin{tabular}{|l|}
$-0,22$ \\
\end{tabular} & 0,10 & $-0,21$ & \begin{tabular}{|l|}
$-0,02$ \\
\end{tabular} & 0,51 & $-0,21$ & 0,10 & 0,66 & \begin{tabular}{|l|l|}
$-0,17$ \\
\end{tabular} & 0,28 & 0,12 & 0,01 & 0,29 & 0,13 & 0,38 & 1,00 & & \\
\hline cars & 0,19 & 0,05 & 0,14 & $-0,07$ & \begin{tabular}{|c|}
$-0,01$ \\
\end{tabular} & 0,53 & $-0,25$ & \begin{tabular}{|l|l|}
$-0,72$ \\
\end{tabular} & \begin{tabular}{|l|}
0,47 \\
\end{tabular} & \begin{tabular}{|l|}
0,04 \\
\end{tabular} & \begin{tabular}{|l|}
0,01 \\
\end{tabular} & 0,50 & \begin{tabular}{|l|}
0,64 \\
\end{tabular} & 0,58 & 0,58 & \begin{tabular}{|l|}
0,24 \\
\end{tabular} & \begin{tabular}{|l|}
0,00 \\
\end{tabular} & 0,20 & $-0,11$ & \begin{tabular}{|l|}
0,17 \\
\end{tabular} & $\begin{array}{l}0,45 \\
\end{array}$ & $-0,32$ & 0,44 & 0,26 & \begin{tabular}{|c|}
$-0,10$ \\
\end{tabular} & 0,45 & 0,27 & 0,20 & 0,25 & 0,38 & 0,39 & 0,50 & 1,00 & \\
\hline $\mathrm{d} w_{\text {ccom }}$ & $-0,13$ & \begin{tabular}{|l|l|}
$-0,14$ \\
\end{tabular} & $-0,30$ & 0,25 & 0,80 & \begin{tabular}{|c|}
$-0,40$ \\
\end{tabular} & 0,20 & \begin{tabular}{|l|}
0,28 \\
\end{tabular} & \begin{tabular}{|l|}
0,04 \\
\end{tabular} & \begin{tabular}{|l|}
0,78 \\
\end{tabular} & \begin{tabular}{|l|l|}
$-0,63$ \\
\end{tabular} & $-0,22$ & \begin{tabular}{|l|}
$-0,29$ \\
\end{tabular} & \begin{tabular}{l|l}
$-0,52$ \\
\end{tabular} & $-0,37$ & \begin{tabular}{|l|l|}
$-0,20$ \\
\end{tabular} & \begin{tabular}{|l|}
$-0,02$ \\
\end{tabular} & $-0,32$ & \begin{tabular}{|l|}
0,18 \\
\end{tabular} & \begin{tabular}{|l|}
0,81 \\
\end{tabular} & $-0,49$ & \begin{tabular}{|l|}
0,55 \\
\end{tabular} & \begin{tabular}{|c|}
$-0,20$ \\
\end{tabular} & 0,28 & \begin{tabular}{|l|}
$-0,65$ \\
\end{tabular} & \begin{tabular}{|c|}
$-0,42$ \\
\end{tabular} & \begin{tabular}{|l|}
$-0,41$ \\
\end{tabular} & \begin{tabular}{|l|}
$-0,52$ \\
\end{tabular} & \begin{tabular}{|l|}
$-0,15$ \\
\end{tabular} & \begin{tabular}{|l|}
$-0,31$ \\
\end{tabular} & \begin{tabular}{|c|}
0,43 \\
\end{tabular} & \begin{tabular}{|c|}
$-0,13$ \\
\end{tabular} & \begin{tabular}{|l|}
0,14 \\
\end{tabular} & 1,00 \\
\hline
\end{tabular}


Table A2: Drivers for Domestic Material Consumption Complete Test Statistic for EU-15, 1980-2000

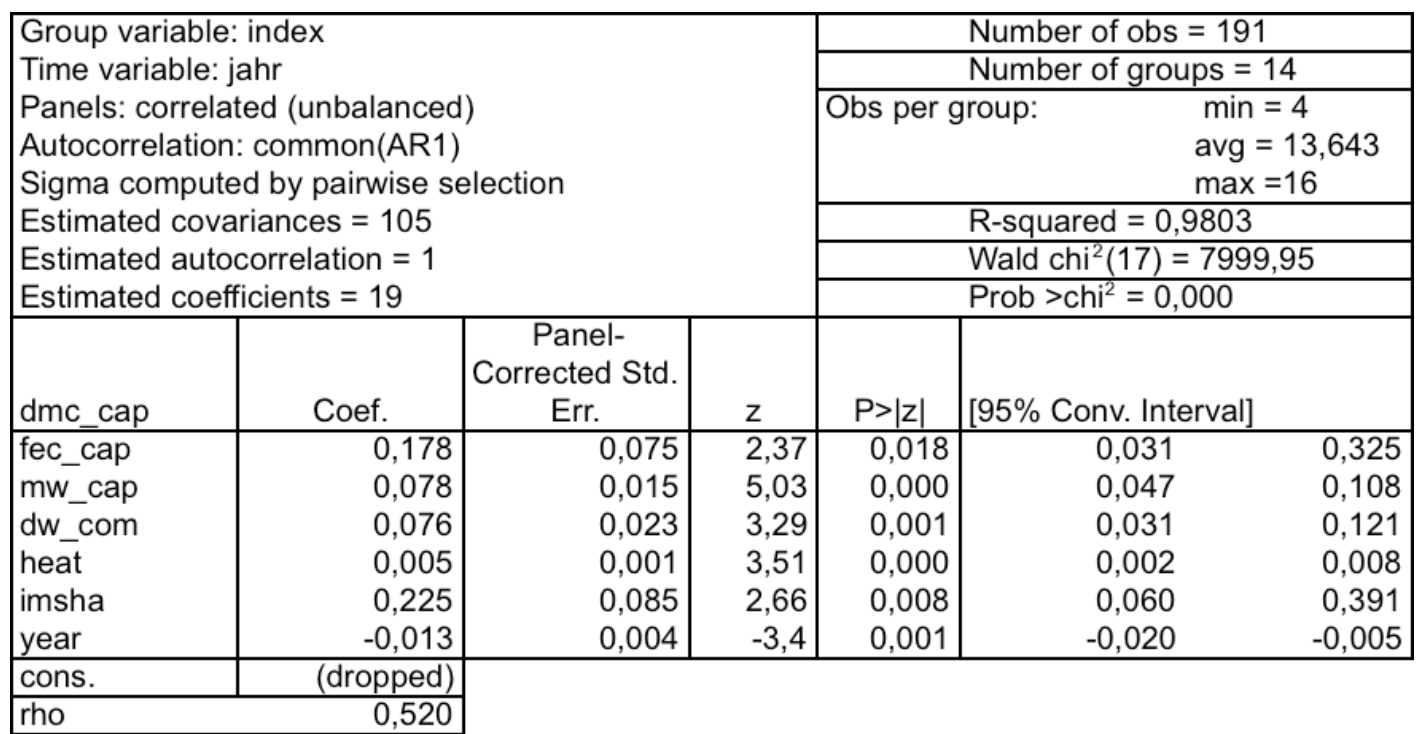

Table A3: Drivers for Domestic Material Consumption Complete Test Statistic for EU-27, 1992-2000

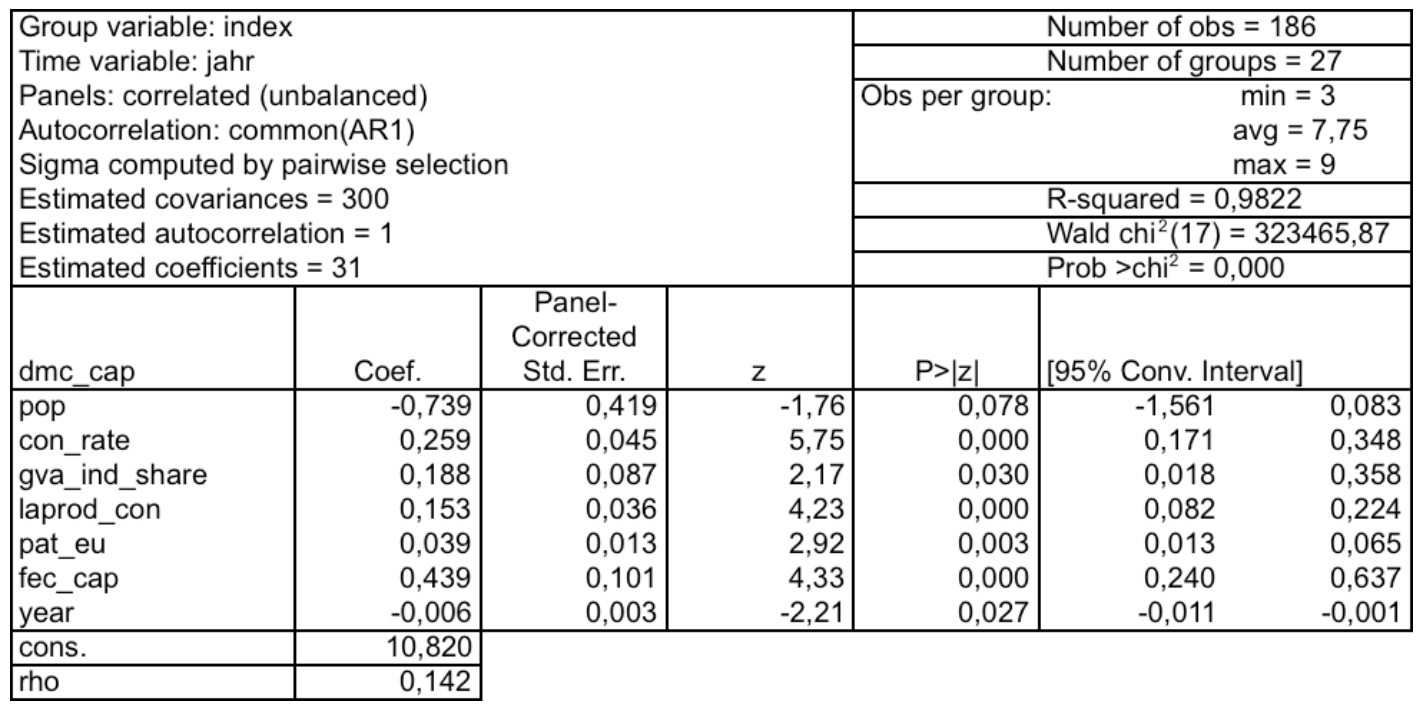


Table A4: Drivers for Material Intensity Complete Test Statistic for EU-15, 1980-2000

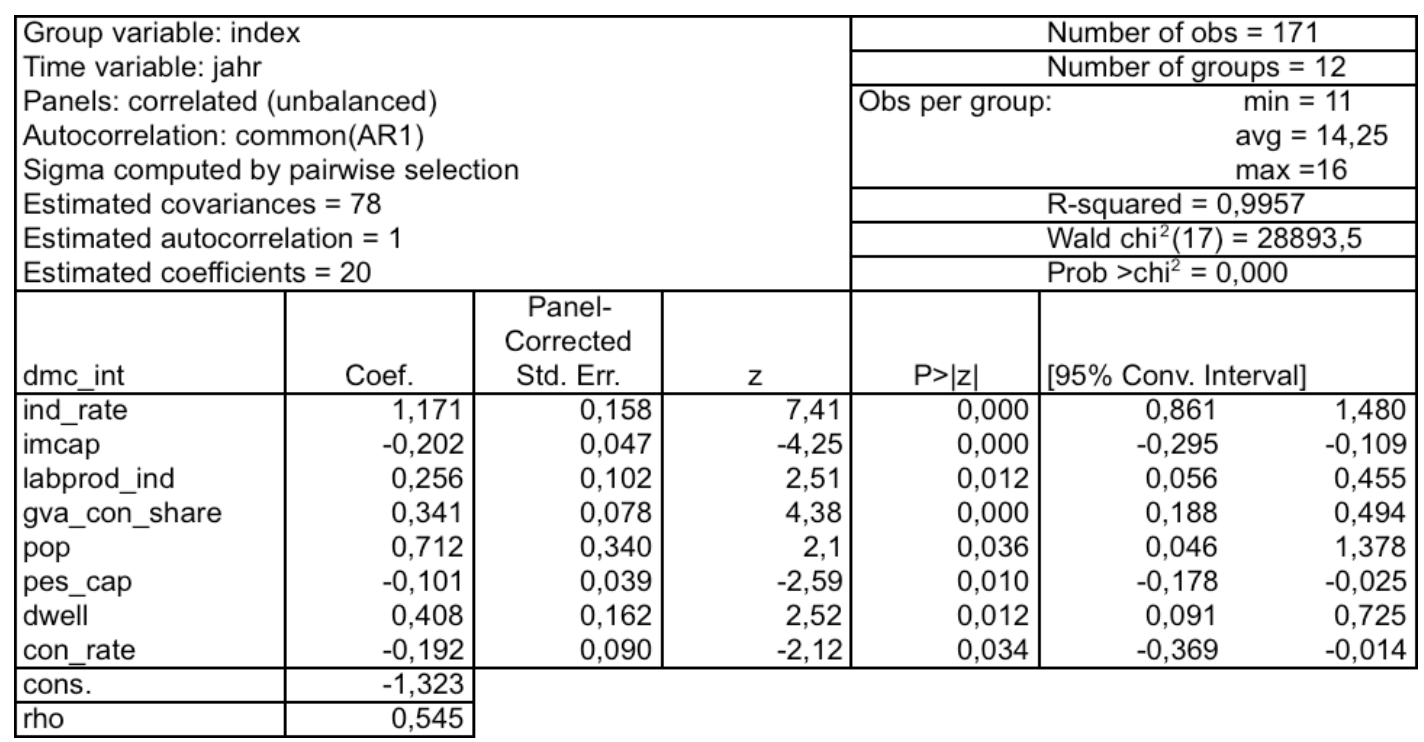

Table A5: Drivers for Material Intensity Complete Test Statistic for EU-27, 1992-2000

\begin{tabular}{|c|c|c|c|c|c|c|}
\hline \multirow{6}{*}{\multicolumn{4}{|c|}{$\begin{array}{l}\text { Group variable: index } \\
\text { Time variable: jahr } \\
\text { Panels: correlated (unbalanced) } \\
\text { Autocorrelation: common(AR1) } \\
\text { Sigma computed by pairwise selection } \\
\text { Estimated covariances }=253 \\
\text { Estimated autocorrelation }=1 \\
\text { Estimated coefficients }=29\end{array}$}} & & \multirow{2}{*}{\multicolumn{2}{|c|}{$\begin{array}{l}\text { Number of obs }=159 \\
\text { Number of groups }=22\end{array}$}} \\
\hline & & & & & & \\
\hline & & & & \multicolumn{2}{|c|}{ Obs per group: } & $\begin{array}{l}\min =1 \\
\operatorname{avg}=7,2273 \\
\max =9\end{array}$ \\
\hline & & & & \multicolumn{3}{|c|}{ R-squared $=0,995$} \\
\hline & & & & \multicolumn{3}{|c|}{ Wald $\operatorname{chi}^{2}(17)=17163,64$} \\
\hline & & & & \multicolumn{3}{|c|}{ Prob $>\mathrm{chi}^{2}=0,000$} \\
\hline dmc int & Coef. & $\begin{array}{c}\text { Panel- } \\
\text { Corrected } \\
\text { Std. Err. }\end{array}$ & z & $\mathrm{P}>|\mathrm{z}|$ & \multicolumn{2}{|c|}{ [95\% Conv. Interval] } \\
\hline ind_rate & 0,336 & 0,163 & 2,06 & 0,039 & 0,016 & 0,656 \\
\hline gva_ser_share & $-1,347$ & 0,242 & $-5,56$ & 0,000 & $-1,822$ & $-0,872$ \\
\hline imcap & $-0,148$ & 0,047 & $-3,14$ & 0,002 & $-0,240$ & $-0,055$ \\
\hline dw_com & 0,044 & 0,026 & 1,73 & 0,085 & $-0,006$ & 0,095 \\
\hline rail_cap & $-0,520$ & 0,152 & $-3,43$ & 0,001 & $-0,817$ & $-0,222$ \\
\hline labprod_ind & $-0,265$ & 0,104 & $-2,54$ & 0,011 & $-0,469$ & $-0,060$ \\
\hline pes_cap̄ & 0,078 & 0,045 & 1,74 & 0,082 & $-0,010$ & 0,166 \\
\hline cons. & 17,524 & & & & & \\
\hline rho & 0,209 & & & & & \\
\hline
\end{tabular}




\section{References}

[1] Acosta-Fernández J, Bringezu S. Sektorale Potenziale zur Verringerung des Ressourcenverbrauchs der deutschen Wirtschaft und ihre Auswirkungen auf Treibhausgasemissionen, Bruttowertschöpfung und Beschäftigung. Wuppertal Institute for Climate, Environment, Energy, 2007.

[2] Ambec S, Johnstone N, Lanoie P, Laurent-Lucchetti J. Environmental Policy, Innovation and Performance: New Insights on the Porter Hypothesis, Working Paper GAEL No. 2007-07, Laboratoire d'Economie Appliquée de Grenoble, June 2007.

[3] Baltagi BH. Econometric Analysis of Panel Data. John Wiley \&. Sons, 1995.

[4] Beck N. Time-Series_Cross-Section Methods. Box-Steffensmeier: 2006.

[5] Beck N, Katz JN. What to Do (and Not to Do) With Time-Series Cross-Section Data. American Political Science Review 1995; 89: 634-647.

[6] Beck N, Katz JN. Modeling Dynamics in Time-Series Cross-Section Political Economy Data. Social Science Working Paper 1304, California Institute of Technology, Pasadena 2009.

[7] Bleischwitz R. Ressorcenproduktivität. Innovationen für Umwelt und Beschäftigung. Berlin, Springer-Verlag. 1998.

[8] Bleischwitz R. Cognitive and Institutional Perspectives of Eco-Efficiency. Ecological Economics 2003; 46: 453-467. 
[9] Bleischwitz R. Governance of Sustainable Development: Co-Evolution of Political and Corporate Strategies. International Journal of Sustainable Development 2004; 7(1): 27-43.

[10] Bleischwitz R. et al. Eco-innovation - putting the EU on the path to a resource and energy efficient economy. Wuppertal-Institut-Spezial 2009; No. 38.

[11] Bleischwitz R, Bahn-Walkowiak B. Aggregates and construction markets in Europe - towards a sectoral action plan on sustainable resource management. 'Minerals and Energy’ 2007 (3-4): 159-176.

[12] Bleischwitz R, Welfens P, Zhang ZX. Sustainable Growth and Resource Productivity Economic and Global Policy Issues. Sheffield, Greenleaf Publisher, 2009.

[13] Breitung J, Das S. Panel unit root tests under cross-sectional dependence. Statistica Neerlandica 2005; 59: 414-433.

[14] Bretschger L. Energy Prices, Growth, and the Channels in Between: Theory and Evidence. CER-ETH Economics Working Paper Series 06/47, ETH Zurich 2009.

[15] Bretschger L. Growth Theory and Sustainable Development. Cheltenham: Edward Elgar 1999.

[16] Bringezu S. Industrial Ecology: Analyses for Sustainable Resource and Materials Management in Germany and Europe. Ayres R, Ayres L, editors. Handbook of Industrial Ecology. Cheltenham / Northampton, Edward Elgar, 2002: 288 - 300.

[17] Bringezu S., Schütz H, Steger S, Baudisch J. International Comparison of Resource Use and its Relation to Economic Growth: the Development of Total Mate- 
rial Requirement, Direct Material Inputs and Hidden Flows and the Structure of TMR. Ecological Economics 2004; 51: 97-124.

[18] Bringezu S, Bleischwitz R, Sustainable Resource Management. Trends, Visions and Policies for Europe and the World. Sheffield: Greenleaf Publisher, 2009.

[19] Brunnermeier SB, Levinson A. Examining the Evidence on Environmental Regulations and Industry Location. Journal of Environment \& Development 2004; (13(1): 6-41.

[20] Canas A, Ferrao P, Conceicao P. Environmental Kuznets Curve? Relationship between Direct Material Input and Income per Capita: Evidence from Industrial Countries. Ecological Economics 2003; 46: 217-229.

[21] Choi I. Unit root tests for panel data. Journal of International Money and Finance $2001 ; 20: 249-272$.

[22] Cleveland CJ, Ruth M. Indicators of Dematerialization and the Materials Intensity of Use. Industrial Ecology 1998; 2: 13-49.

[23] de Bruyn S, Markowska A, de Jong F, Blom M. Resource productivity, competitiveness and environmental policies, CE Delft 2009.

[24] EEA. Guidelines for Data Collection and Processing - EU State of the Environment Report. Copenhagen; 1998.

[25] Giljum S, et al. Modelling Scenarios towards a sustainable use of natural resources in Europe. Environmental Science \& Policy 2008; 11(3): 204-216.

[26] Granger CWJ, Newbold, P Spurious regressions in econometrics. Journal of Econometrics 1974; 2: 111-120. 
[27] Greene W. Econometric Analysis. 5 edition. Upper Saddle River, N.J.: Prentice Hall., 2005.

[28] Hadri K. Testing for stationarity in heterogeneous panel data. Econometrics Journal 2000; 3: 148-161.

[29] Harris RDF, Tzavalis E. Inference for unit roots in dynamic panels where the time dimension is fixed. Journal of Econometrics 1999; 91: 201-226.

[30] Heckman JJ. Causal Parameters and Policy Analysis in Economics: A Twentieth Century Retrospective. Quarterly Journal of Economics 2000; 2: 45-97.

[31] Hödl E. Sustainable Growth and Resource Productivity - Economic and Global Policy Issues. In: Bleischwitz R, Welfens PJJ, Zhang Z. editors. Sheffield: Greenleaf Publisher; 2009.

[32] Hsiao C, Analysis of Panel Data, Cambridge University Press 2 edition. 2002.

[33] Im KS, Pesaran MH, Shin Y. Testing for unit roots in heterogeneous panels. Journal of Econometrics 2003; 115: 53-74.

[34] Jackson T. Prosperity without growth? The transition to a sustainable economy, Sustainable Development Commission UK. London; 2009.

[35] Kittel B. Sense and Sensitivity in Pooled Analysis of Political Data. European Journal of Political Research 1999; 38:225-254.

[36] Krausmann F, Gingrich S, Eisenmenger N, Erb KH, Haberl H, FischerKowalski M. Growth in global materials use, GDP and population during the 20th century. Ecological Economics 2009; 68 (10): 2696-2705.

[37] Levin ACF, Lin CF, Chu CSJ. Unit root tests in panel data: Asymptotic and finite-sample properties. Journal of Econometrics 2002; 108: 1-24. 
[38] Malerba F. Innovation and the dynamics and evolution of industries: Progress and challenges. International Journal of Industrial Organization, 2007; 25(4), 675699.

[39] Malenbaum W. World Demand for Raw Materials in 1985 and 2000, New York: McGraw-Hill: 1978.

[40] Nelson R, Winter SG. An Evolutionary Theory of Economic Change, Cambridge: Harvard University Press: 1982.

[41] Nelson R, Winter SG. Evolutionary Theorizing in Economics. Journal of Economic Perspectives 2002; 16(2): 23-46.

[42] Niemeijer D, Groot de RS. Framing environmental indicators: moving from causal chains to causal networks. Environment, Development and Sustainability 2008; 10 (1): 89-106.

[43] North D. Institutions, Institutional Change and Economic Performance. Cambridge: Cambridge University Press, 1990.

[44] OECD Measuring Material Flows and Resource Productivity. Vol. I - III and a Synthesis report, Paris, Organisation for Economic Development and Cooperation 2008.

[45] OECD Environmental Indicators - OECD Core Set. Paris, Organisation for Economic Development and Cooperation 1994.

[46] Ostrom E, Burger J, Field CB, Norgaard RB, Policansky D. Revisiting the Commons: Local Lessons, Global Challenges, Science. 1999; 284: 278-82. 
[47] Plümper T, Troeger VE, Manow P. Panel data analysis in comparative politics. Linking method to theory. European Journal of Political Research 2005; 44: 327 354.

[48] Porter M, van der Linde C. Toward a New Conception of the Environment Competitiveness Relationship. Journal of Economic Perspectives 1995; 9(4): 97118.

[49] Scott KA. Literature Review on Sustainable Lifestyles and Recommendations for Further Research, Stockholm Environment Institute, 2009.

[50] Steger S, Bleischwitz R. Entkoppelung der Ressourcennutzung vom Wachstum : wie erfolgreich ist Europa bei der Erhöhung der Ressourcenproduktivität und einer Dematerialisierung? Rudolph S, editors. Wachstum, Wachstum über alles? Ein ökonomisches Leitbild auf dem Prüfstand von Umwelt und Gerechtigkeit. Marburg: Metropolis-Verlag, 2007: 101-129.

[51] Steger S, Bleischwitz R. Decoupling GDP from resource use, resource productivity and competitiveness: a cross-country comparison. Bleischwitz R, Welfens P, Zhong ZX, editors. Sustainable Growth and Resource Productivity - Economic and Global Policy Issues. Sheffield: Greenleaf Publisher, 2009.

[52] Stock JH, Watson MW. Introduction to Econometrics. Addison-Wesley: 2003. [53] Tukker A, Huppes G, Suh S, Heijungs R, Guinèe J, de Koning A, Geerken T, Jansen B, van Holderbeke M, Nielsen P. Environmental Impacts of Products. Analysis of the Life Cycle Environmental Impacts related to the Total Final Consumption of the EU25. Sevilla, ESTO/IPTS, 2005. 
[54] van der Voet E., van Oers L, Moll S, Schütz H, Bringezu S de Bruyn S, Sevenster M, Warringa G. Policy Review on Decoupling: Development of indicators to assess decoupling of economic development and environmental pressure in the EU25 and AC-3 countries, Leiden/Wuppertal/Delft, Institute of Environmental Sciences (CML)/Wuppertal Institute for Climate, Environment and Energy/CE Solutions for Environment, Economy and Technology, 2005.

[55] Vergragt PJ, Brown HS. Sustainable mobility: from technological innovation to societal learning. Journal of Cleaner Production 2007;15(11-12): 1104-1115.

[56] Wagner M. The Porter Hypothesis Revisited: A Literature Review of Theoretical Models and Empirical Tests, Centre for Sustainability Management (CSM), University of Lüneburg, Germany 2003.

[57] Westerlund J. Testing for Error Correction in Panel Data. Oxford Bulletin of Economics and Statistics 2007; 69(6): 709-748.

[58] Weisz H, Amann Ch, Eisenmenger N, Hubacek K, Krausmann F. Development of Material Use in the European Union 1970 - 2001. Material Composition, CrossCountry Comparison, and Material Flow Indicators. Eurostat Working Papers. Luxembourg, 2002.

[59] Weisz H, Krausmann F, Amann C, Eisenmenger N, Erb KH, Hubacek K, Fischer-Kowalski M. The Physical Economy of the European Union: CrossCountry Comparison and Determinants of Material Consumption. Ecological Economics 2006; 58(1): 676-698. 
[60] Wilson SE, Butler DM. A Lot More to Do: The Sensitivity of Time-Series Cross-Section Analyses to Simple Alternative Specifications. Political Analysis 2007; 15:101-123.

[61] Wooldridge JM. Econometric analysis of cross section and panel data. Cambridge, MA: MIT Press 2002.

[62] Xing Y, Kolstad CD. Di lax environmentaö regulation attract foreign investment? Environmental and Resource Economics. 2002; 21:1-22. 